\title{
Toward the Inhuman: Mapping the Micropolitics of Minor Literature in Beloved
}

\author{
Che-ming Yang \\ Associate Professor, Department of Foreign Languages and Literature \\ National Cheng Kung University, 1 University Road, Tainan 701, Taiwan \\ E-mail: yang5692@mail.ncku.edu.tw
}

\author{
Received: March 28, $2011 \quad$ Accepted: September 28, $2011 \quad$ Published: February 1, 2012 \\ doi:10.5539/ijel.v2n1p128 \\ URL: http://dx.doi.org/10.5539/ijel.v2n1p128
}

\begin{abstract}
This paper explores Toni Morrison's most celebrated novel-Beloved, which, just like The White Hotel, (re)presents a historical trauma (slavery). I intend to take one step further beyond the existing scholarship by employing a Deleuzian (micro)politics of minor language/literature as well as a schizoanalysis (against Freudian psychoanalysis) of the deterritorialization of the main characters (the baby ghost excluded) in Beloved-Sethe, Paul D, and Denver (Sethe's daughter). To be more specific, through exploring the main characters' deterritorialization of slavery and its haunting shadow (the unspeakable horror and pain) in this novel, this paper aims to achieve a mapping (the Deleuzian term for a proper attitude of approaching the contingent realities) of a Deleuzian poetics/problematics of how to create a minoritarian language (Black English) for (re)presenting an extraordinary vision of the collective traumatic memory of extreme suffering, brutality, and inhumanity embodied in this exceptionally breathtaking novel.
\end{abstract}

Keywords: Deleuzian, Schizoanalysis, Minoritarian language/literature, Deterritorialization, Freudian psychoanalysis

\author{
We had fed the heart on fantasies, \\ The heart's grown brutal from the fare; \\ More substance in our enmities \\ Than in our love ... \\ -W. B. Yeats, "Meditations in Time of Civil War"
}

\section{Introduction}

Though having inspired enormous controversy, undoubtedly, Toni Morrison's Beloved has become the author's most celebrated and analyzed works. Many critics worldwide have done some analysis on this novel's dehumanizing effects of slavery, how memory/history has haunted man's psyche, and the (im)possibility of forgiveness for the outrageous historical trauma. Above all, when slavery has torn apart one's heritage, when the past is more vivid and enduring than the present, when the rage of a baby's ghost can even ruin the house and its family, we can claim that any traditional novel is no longer an adequate means of (re)presenting such a catastrophic experience.

In her novels, Morrison's style greatly mirrors her content-unconventional and deterritorialized, which is in great contrast to many Western novels. As Rigney has brilliantly put it,

Toni Morrison represents an exemption form 'phallocratic law'; her own language and her theory of language, as she has demonstrated in her five novels [Beloved as the fifth one that was published in 1987] and explained in a number of essays and interview, reflect a consciousness that she writes both from and about a zone that is 'outside' of literary convention, that disrupts traditional Western ideological confines and modifies patriarchal inscriptions. (1)

Nevertheless, most of the existent Morrison scholarship about Beloved is centered on her experimental/postmodernist (re)presentation of the quest/struggle for racial/cultural identity of 
African-Americans in a dominant white culture, the challenge of facing their historical trauma, or her extraordinarily varied and experimental narrative modes. (Note 1)

Given the above-mentioned, though the existent scholarship on Toni Morrison and Beloved is already quite abundant, my study of this novel aims to be an "uncommon" one, for I intend to take one step further by employing a Deleuzian (micro)politics of minor literature as well as a schizoanalysis (against Freudian psychoanalysis) of the deterritorialization of the main characters (the baby ghost excluded) in Beloved - Sethe, Paul D, and Denver (Sethe's daughter).

To be more specific, through exploring the main characters' deterritorialization of slavery and its haunting shadow (the unspeakable horror and pain) in this novel, this paper aims to achieve a mapping (the Deleuzian term for a proper attitude of approaching the contingent realities) of a Deleuzian poetics/problematics to analyze Morrison's strategies in (re)presenting an extraordinary vision of the collective traumatic memory of extreme suffering, brutality, and inhumanity embodied in this exceptionally breathtaking novel.

\section{Sethe as a Schizo/Masochist Body: The Deterritorialization of Becoming-Inhuman}

"For a baby she throws a powerful spell," said Denver.

"No more powerful than the way I loved her," Sethe answered and there it was again.

... But what she got, settled for, was the one word [Beloved] that mattered. She though it would be enough .... (Morrison, 1987, p. 5) (Note 2)

The most horrifying and controversial event in Beloved is Sethe's infanticide. How can a mother have done such atrocity to her child and how can she even has the heart and nerve to claim that she did that for her child's good? This horrifying act can be reexamined from a Deleuzian perspective. In A Thousand Plateaus Deleuze highly values becoming-woman, "all becomings begin and pass through becoming-woman" (Colebrook 139). All becomings are molecular, intended to form lines of flight. For Sethe, this atrocious act is out of extremely deep love, which is clearly marked by the epigraph above - she even has sex with the man so that the inscription "Beloved" can be carved on the murdered child's tombstone (5) (Note 3). Many people reject her because of her infanticide and thus regard her as "insane." But Sethe insists that she has done nothing wrong, for she argues that she has saved her child from pre-slavery with her "thick love":

"Your love is too thick," he said, thinking, That bitch is looking at me; she is right over my head looking down through the floor at me.

"Too thick?" she said, thinking of the Clearing where Baby Suggs' commands knocked the pods off horse chestnuts. "Love is or it ain't. Thin love ain't love at all." (173)

According to Deleuze and Guattari, Sethe's lines of flight are becoming-animal or becoming-imperceptible by

approaching or imaging the inhuman point of view of animals, machines and molecules we no longer take ourselves as unchanging perceivers set over and against life. We immerse ourselves in the flow of life's perceptions. The human becomes more than itself, or expands to its highest power, not by affirming its humanity, but by becoming-hybrid with what is not itself. This creates 'lines of flight'; from life itself we imagine all the becomings of life, using the human power of imagination to overcome the human. (Colebrook, 2002, p.128-29)

It is this inhuman perspective on life/humanity that makes Sethe commit infanticide, which did rid the murdered child of slavery at the cost of her life. Nevertheless, the traumatic experience of the past is always haunting her, just like the baby ghost. By becoming-animal or imperceptible, Sethe has already made herself a body without organs $(\mathrm{BwO})$. $\mathrm{BwO}$ is not opposed to organs but "to that organization of the organs called the organism" (Deleuze and Guattari, 1992, p. 158).

BwO, argue Deleuze and Guattari, and its "true organs," which must be composed and positioned, are opposed to

the organism, the organic organization of the organs. The judgment of God, the system of the judgment of God, the theological system, is precisely the operation of He who makes an organism ... (Deleuze and Guattari, 1992, p. 158)

$\mathrm{BwO}$ is also the embodiment of the intensities of deterritorialization. In Beloved, Sethe resorts to an outrageous act for evading slavery after desperately running away with her children. Upon being caught, out of "thick love," she would rather kill them than restore them into the inhuman and dehumanizing organism of slavery.

But how does Sethe make herself a BwO? According to Deleuze and Guattari, “you make one, you can't desire 
without making one"; namely, $\mathrm{BwO}$ is the natural product of desiring:

And it $[\mathrm{BwO}]$ awaits you; it is an inevitable exercise or experimentation, already accomplished the moment you undertake it ... Or it can be terrifying, and lead you to your death [emphasis added]. It is nondesire as well as desire. It is not at all a notion or a concept but a practice, a set of practices. You never reach the Body without Organs, you can't reach it, you are forever attaining it, it is a limit. (Deleuze and Guattari, 1992, p. 150)

Sethe is always on the process of attaining a $\mathrm{BwO}$ before she is fully redeemed from the haunting memory of slavery and infanticide. When she deterritorializes the slavery and kills her child, her desire makes her a $\mathrm{BwO}$ that is becoming- "already accomplished the moment she undertakes it." But later, she seems to fall into the abyss of great sense of sorrow and remorse and thus is still "attaining" it instead of "reaching" it. Morrison's Beloved seems to imply that the victims of slavery can never be healed of their historical trauma. And its aftermath is so powerful that they can never pass it on.

The $\mathrm{BwO}$ is a long procession and it starts "the moment the body has had enough of organs and wants to slough them off, or loses them" (Deleuze and Guattari, 1992, p.150). According to Deleuze and Guattari, it has six basic forms/incarnations, two among which are the schizo body and the masochist body. These are the two derivatives of $\mathrm{BwO}$ that can well explain Sethe's becomings in taking her line of flight. And the process is a sort of delirium that betrays the hegemonic powers:

A flight is a sort of delirium. To be delirious is exactly to go off the rails ... There is always a betrayal in a line of flight. ... We betray the fixed powers which try to hold us back, the established powers of the earth. The movement of betrayal has been defined as a double turning-away . . . (Deleuze and Parnet, 1977, p. 40)

Sethe's line of flight is her betrayal of the slavery and becoming-inhuman when ridding her children of slavery by taking extreme action. By so doing, she becomes a schizo body as well as a masochist body.

A schizo body is one that wages "its own active internal struggle against the organs, at the price of catatonia"; whereas the masochist body is "poorly understood in terms of pain; it is fundamentally a question of the $\mathrm{BwO}$. It has its sadist or whore sew it up . . . It has itself strung up to stop the organs from working" (Deleuze and Guattari, 1992, p.150). In terms of Baby Suggs's case, "her past had been like her present—intolerable — and since she knew death was anything but forgetfulness, she used the little energy left her for pondering color" (6). Her only way out of the haunting memory of slavery is to indulge herself in "color." As for Sethe, not only betraying the oppression of slavery by digressing from the earthly standards of parental love, she also inflicts pain on herself because of murdering her own child. But she seems to take it lightly. In terms of the self-inflicting pain caused by killing her beloved child, her masochist body is hard to understand for the outsiders, for they fail to recognize her infanticide as her line of flight from the inhuman slavery.

But her schizo body has made her transcended the limits of her organs to gain a vision of redemption from the suffering of slavery and its aftermath. She has a troubled relationship with her own past, frequently not willing to speak about it, for she has shut down all the organs inside her body to communicate with the outside world. Rather, she obsessively relives her traumatic past inside her own head. She has a mass of scars on her back that resemble a tree-the tree scars. These tree scars are like the oppressive powers of slavery-the arborescent ideology that is aimed at justifying the abuse of the blacks and her obsession with this traumatic experience. Her desperate line of flight does not even win sympathy among the black community. Moreover, the tree scars also signify that the trauma is incurable and enduring. To escape from the enormously oppressive organism of slavery, Sethe has to make herself a schizo body and thus liberate her libidinal flows that function like a rhizome (a deterritorializing movement) in opposition to the arborescent ideology of the white men- "Every rhizome contains lines of segmentarity according to which it is stratified, territorialized, organized, signified, attributed, etc., as well as lines of deterritorialization down which it constantly flees. . . . the line of flight is part of the rhizome" (Deleuze and Guattari, 1992, p.9).

\section{Toward a Minor Literature: The Impossible Writing of the Black Diaspora}

It is impossible to define a feminist practice of writing, and this is an impossibility that will remain, for this practice can never be theorized, enclosed, coded — which doesn't mean that it doesn't exist. . . . It will be conceived of only by subjects who are breakers of automatisms, by peripheral figures that no authority can ever subjugate. (Note 4)

Undoubtedly, Morrison is one of these "peripheral figures" in terms of the dominant culture, "central though she is to the contemporary literary scene" (Rigney, 1991, p.2). As I had mentioned in Chapter II, in Deleuzian terms, 
she has been writing in a deterritorialized language and thus creates a minor literature.

Furthermore, Deleuze and Guattari claim that the blacks in America today are facing the same problems with Kafka, for they are using a language that is not their own. The black English is a deterritorialized language, "appropriate for strange and minor uses" (Deleuze and Guattari, 1986, p. 17) - the first characteristic of minor literature. Nevertheless, a minor literature does not come from a minor language, although it may be the case; it is rather "that which a minority constructs within a major language" (Deleuze and Guattari, 1986, p. 16). Like many marginalized people and minorities, the African-Americans have to create "a unique and solitary writing" within a major language and culture:

How many people today live in a language that is not their own? Or no longer, or not yet, even know their own and know poorly the major language that they are forced to serve? This is the problem of immigrants, and especially of their children, the problem of minorities, the problem of a minor literature, but also a problem for all of us [emphasis added]: how to tear a minor literature away from its own language, allowing it to challenge the language and making it follow a sober revolutionary path? How to become a nomad and an immigrant and a gypsy in relation to one's own language? Kafka answers: steal the baby from its crib, walk the tightrope. (Deleuze and Guattari, 1986, p. 19)

In Beloved, Morrison seems to be highlighting this sense of alienation by having Sethe and Denver remain alone and excluded from even the black community, their fellowmen, who have been already incorporated into the white ideology and thus despise Sethe and Denever. Moreover, the tone of Morrison seems to be merged with the characters in the novel. In other words, her fate has been tied with that of the characters as "peripheral figures." Morrison has been challenging the dominant language —English — in her minor writing; namely, making a minor usage of the major language. In addition, just like Kafka's strategy in minor writing as shown above, Morrison has made English "follow a sober revolutionary path" by immersing the blacks' syntax and expressions in English narrativization. Likewise, there is Sixo, another slave at Sweet Home, who "stopped speaking English because there was no future in it" (125) and thus made himself a nomad, remaining a foreigner in his "own" language (English).

According to Deleuze and Guattari's general approach to language, "major" and "minor" are

not simply opposed to one another as the individual to the collectivity. Every language presumes collective assemblages of enunciation, nondiscursive machinic assemblages and an abstract machine that distributes and interrelates these assemblages. Strictly speaking, "there is no subject, there are only collective assemblages of enunciation" [Deleuze and Guattari, 1986, p. 18]. (Bogue, 2002, p. 109)

In other words, Deleuze and Guattari argue that language is a social creation, whose rules, conventions and other elements are invented by the society instead of individuals.

Given the above-mentioned, we can see that the narrative mode of Beloved corresponds to the characteristics of a minor writing, for each of the main black characters (i.e. Sethe, Denver, Paul D, Beloved) seems to be interchangeable in their streams-of-consciousness. As many critics, such as Carmean, have pointed out, Morrison tries to create an impression that it is the character who is speaking, not the writer who is speaking for him or makes him speak with the authorial voice:

She wants it to appear as though no author tells the story. The narratives simply start and go on, apparently without a definite structure, unfolding and meandering in various directions all at once, it seems. This approach may on the surface sound chaotic, but of course it isn't. Holding everything together is a guiding voice. This voice, however, although heard throughout the narrative, is not easily identified because Morrison avoids using a simple and personally authoritative point-of-view. She tries to create an illusion that the point-of-view belongs to the multiple characters. . . . In a directly technical sense, Morrison is obviously the narrator, and it is her personal voice that slides "in' and "out" of her various characters. When she is "out," however, the reader doesn't suddenly discover a narrative authority commenting on or pointing to the text. The story continues as if it were just told by no one in particular [emphasis added]. (11).

Carmean's view of the intersubjectivity of the multiple narrators in this novel happens to echo what Linda Hutcheon (1988) claimed in her analysis of the subject of the female protagonist-Lisa-in The White Hotel: "the female protagonist is not fully or consistently a traditional Jamesian centre of consciousness with whom the 
reader can identify as subject" (161).

Furthermore, the contingent and multiple point of view is also characteristic of the Deleuzian minor literature-becoming-imperceptible or becoming-inhuman, which is embodied by Sethe's inexplicable infanticide, because she has made herself a body without organs and thus is able to imagine life from an inhuman perspective. Moreover, Morrison's writing destroys this border between the perceiver and the perceived; namely, Morrison's politics of writing is to create a delirium, characteristic of Deleuzian minor writing/literature, for it has the power and potential to speak with, and write with the outside world that is always on the way of becoming. And it has the potential to invent a people that are not recognized yet - a minor literature is both political and collective. In the absence of the 60 million blacks who had died in slavery, Morrison is one of the writers who are marginalized and solitary and thus is in the best position "to express another potential community" (Deleuze and Guattari, 1986, p. 17). But if she does so, she no longer writes as an individual subject, for "the most individual literary enunciation is a particular case of collective enunciation" (Deleuze and Guattari, 1986, p. 83-84).

To see more correspondences between Morrison's writing and minor literature, now, I would like to analyze how Morrison creates an impossible writing or a minor literature of impossibility based on the Deleuzian aesthetics/micropolitics of minor literature.

In several interviews, Morrison pointed out that she intended to dedicate Beloved to the 60 million blacks who died as a result of slavery, for she felt a strong impulse to (re)present that historical trauma that has already become a "national amnesia":

Some historians told me 200 million died. The smallest number I go from anybody was 60 million. . . . I thought this [Beloved] has got to be the least read of all the books I'd written because it is about something that the characters don't want to remember, I don't want to remember, black people don't want to remember, white people won't want to remember. I mean, it's national amnesia. (Angelo, 1989, p. 121)

This is characteristic of an impulse toward minor literature, for Morrison, just like Kafka, aims to highlight "the impasse that bars access to writing" (Deleuze and Guattari, 1986, p. 16) for the blacks in America and turns their literature into something impossible. In Morrison's case, it is an impasse that marks three levels of impossibility--the impossibility of not writing, the impossibility of writing in English, and the impossibility of writing otherwise. (Note 5)

First of all, in terms of Morrison's condition, the impossibility of not writing results from "national consciousness, uncertain or oppressed, necessarily exists by means of literature ('The literary struggle has its real justification at the highest possible levels')" (Deleuze and Guattari, 1986, p. 16). Above all, Beloved's story is "not a story to pass on" (275), for "pass on" has multiple meanings. According to Perez-Torres,

"Pass on" signifies "both rejection and acceptance. Beloved's story cannot be repeated, the narrative warns, cannot be allowed to occur again in the world. The repeated warning also means that this is a story that cannot be forgotten, that cannot be rejected or "passed" on. (1997, p. 93)

In addition, as a story not to pass on, Beloved reveals a paradoxical aspect of existence - "the interplay between presence and absence, accepting and rejecting, appearing and disappearing, repeats and resurfaces throughout the course of Beloved" (Perez-Torres, 1997, p. 93). The reader is placed in a world that flows somewhere between an absent past and an absent future. Sethe, Paul D. and other characters in this novel are representatives of the identity crisis for the black Diaspora. Their past is cut off from their motherland; their future is cut off from the masses of the new land.

Secondly, the impossibility of writing other than in English is for the Afro-Americans the feeling of an irreducible distance from their primitive African territoriality. The blacks have lost their ties with their motherland because of slavery.

Thirdly, the impossibility of writing in English is the deterritorialization of the American white community itself. The Afro-Americans in slavery are an oppressive minority that speaks/writes "a language cut off from the masses, like a 'paper language' or an artificial language," for the blacks are, like the Jews, simultaneously a part of this minority and excluded from it" (Deleuze and Guattari, 1986, p.16-17). Black English is a deterritorialized language, appropriate for minor usage. Morrison herself also admits her experimental utilization of English, for she wishes to accomplish "something that has probably only been fully expressed in music... Writing novels is a way to encompass this - this something" (McKay, 1987, p. 1, quoted in Rigney, 1991, p. 7). Sethe often "recounts her 'rememories' in the form of songs, made-up ballads for her children, which constitute a 
transmission of history and of culture, but it is also her conversation even their thoughts which are musical" (Rigney 9). Moreover, Morrison often emphasizes that music and singing of women have a power beyond words, a transcendent meaning that can provide "the right combination, the key, the code, the sound that broke the back of words . . . a wave of wound wide enough to sound deep water and knock the pods off chestnut trees" (Morrison, 1987, p. 261).

To sum up, what is subtle and complex is Morrison's (representing all the oppressed blacks) minor utilization of the major language - English — by making herself "a foreigner" within her own language, though it is not her real native language. In fact, the African-Americans speak English but are cut off from the masses (white Americans). According to Deleuze and Guattari, even a major language is subject to "an intensive utilization that makes it take flight along creative lines of escape which, no matter how slowly, no matter how cautiously, can now form an absolute deterritorialization" (Deleuze and Guattari, 1986, p. 26). To further explain the hybridity and contingency of language, Deleuze and Guattari argue that

There is no ideal speaker-listener, any more than there is a homogeneous linguistic community. Language is, in Weinreich's words, "an essentially heterogeneous reality." (Deleuze and Guattari, 1992, p.7)

Hence, English today in America has been undergoing a lot of metamorphosis by the minorities or immigrants that try to deterritorialize it.

\section{Conclusion}

Morrison's writing represents a deterritorialization of both language and oppression. Her language speaks "what is unspeakable for mainstream discourse: the juxtaposition of woman and collective history, dissolution of boundaries between signs and historical events, the unification of myth and cultural codes, the reinscription of meaning itself through a rendering of identification and desire" (Rigney 105). Her minor literature does write for the oppressed black community and the misrepresented history of slavery by deterritorializing both English and history and thus creates a people to come. It is hard to put a label on her, because she is many things at the same time- - (black) feminist, a postmodernist, a deconstructionist, a African-American writer who writes for the oppressed minority in pursuit of identity. But maybe she is all of them (Rigney, 1991, p.105).

Anyway, in her most celebrated novel Beloved, Morrison successfully invents an absent people and (re)presents the unspeakable and unpresentable historical trauma in the collective memory of the slavery. Just like Thomas in The White Hotel, Morrison has effectively aligned her fate with that of the marginalized and oppressed black people. Furthermore, in her powerful minor literature, she also creates another group of people that is always on the way of becoming - the readers who take sides with her people out of sympathy after they are overwhelmed by the vision of extreme inhumanity in the slavery, which happens to prompt them into recovering the "national amnesia" that is always not a story to pass on.

\section{References}

Angelo, Bonnie. (1989). The Pain of Being Black: An Interview with Toni Morrison. Time, 133.21 (22 May 1989): $120-23$

Bakhtin, Mikhail. (1981). Dialogic Imagination: Four Essays. Trans. Caryl Emerson. Austin: U of Texas P.

Bogue, Ronald. (2002). Gilles Deleuze and Felix Guattari. Postmodernism: The Key Figures. Eds. Hans Bertens and Joseph Natoli. Oxford: Blackwell.

- - -. (2003). Deleuze on Literature. London: Routledge.

Brooke-Rose, Christine. (1991). Stories, Theories and Things. Cambridge: Cambridge UP. http://dx.doi.org/10.1017/CBO9780511518621

Buchanan, Ian \& John Marks,eds. (2000). Deleuze and Literature. Edinburgh: Edinburgh UP.

Carmean, Karen. (1993). Toni Morrison's World of Fiction. Troy: Whitston.

Colebrook, Claire. (2002). Gilles Deleuze. London: Routledge.

Currie, Mark, ed. (1995). Metafiction. London: Longman.

Deleuze, Gilles \& Claire Parnet. (1977). Dialogues. Trans. Hugh Tomlinson and Barbara Hobberjam. New York: Columbia UP.

Deleuze, Gilles. (1983). Nietzsche and Philosophy. New York: Columbia UP.

- - - (1997). Essays Critical and Clinical. Trans. Daniel W. Smith and Michael. A. Greco. Minneapolis: U of 
Minnesota P.

Deleuze, Gilles \& Fèlix Guattari. (1984). .Anti-Oedipus: Capitalism and Schizophrenia. London: Athlone.

- - - (1986). Kafka: Toward a Minor Literature. Trans. Dana Polan. Minneapolis: U of Minnesota P.

- - -. (1992). A Thousand Plateaus: Capitalism and Schizophrenia. London: Athlone.

Holland, Eugene W. (1999). Deleuze and Guattari's Anti-Oedipus: Introduction to Schizoanaylsis. London: Routledge.

Hutcheon, Linda. (1980). A Theory of Parody: The Teachings of Twentieth-Century Art Form. London: Methuen. - - -. (1988). A Poetics of Postmodernism: History, Theory, Fiction. New York: Routledge.

Lucy, Niall. (1997). Postmodern Literary Theory. Oxford: Blackwell.

Luo, Guei-shiang. (1997). Gilles Deleuze. Taipei: Dung-Da.

Lyotard, Jean-Francois. (1985). The Postmodern Condition: A Report on Knowledge. Minneapolis: Minnesota UP.

Marks, John. (1998). Gilles Deleuze: Vitalism and Multiplicity. London: Pluto.

McHale, Brian. (1987). Postmodernist Fiction. London: Methuen. http://dx.doi.org/10.4324/9780203393321

Morrison, Robert. (1997). Nietzsche and Buddhism: A Study in Nihilism and Ironic Affinities. Oxford: Oxford UP.

Morrison, Toni. (1987). Beloved. New York: Plume.

Perez-Torres, Rafael. (1997). Knitting and Knotting the Narrative Thread. Toni Morrison: Critical and Theoretical Approaches. Ed. Nancy J. Peterson. Baltimore: John Hopkins UP.

Rigney, Barbara Hill. (1991). The Voices of Toni Morrison. Columbus: Ohio State UP.

Rose, Margaret. (1993). Parody: Ancient, Modern, and Post-modern. Cambridge: Cambridge UP.

Waugh, Patricia. (1984). Metafiction: The Theory and Practice of Self-Conscious Fiction. London: Methuen.

Woods, Tim. (1999). Beginning Postmodernism. Manchester: Manchester UP.

\section{Notes}

Note 1. Karen Carmean in her study of Morrison_Toni Morrison's World of Fiction (1993) —argues that on one hand Morrison is writing like no other novelist, on the other hand "there is the critical tendency to draw overly strict comparisons between her way of writing and other traditions or fashions. Thus, she has sometimes been called a magical realist, sometimes a mythical symbolist" (7).

Note 2. Toni Morison, Beloved, *New York: Penguin, 1987). All the subsequent quotes from the novel Beloved will only be marked by their page numbers according to the pagination of this version.

Note 3. See the above epigraph of this section. It is a quote from Beloved, p. 5.

Note 4. See Hélène Cixous and Catherine Clément in The Newly Born Woman, p.313, quoted in Barbara Hill Rigney's introduction to The Voices of Toni Morrison (1991).

Note 5. In Kafka, Deleuze and Guattari describe Kafka's minor literature as something impossible--"the impossibility of not writing, the impossibility of writing in German, the impossibility of writing otherwise" (16). Here, I appropriate these phrasings to analyze Morrison's "black writing," for both of them belong to a marginalized people living in a country where they are cut off from a major language of the dominant group of people. 